'DOSSIÊ: "Didática e formação de professores"

\title{
Why from Didactics the teacher's education is not favored? ${ }^{12}$ \\ ¿Por qué desde la Didáctica no se favorece la formación del profesorado?
}

Agustin de La Herrán Gascón (i)

Ivan Fortunato (ii)

(i) Universidad Autónoma de Madrid - UAM, Madrid, España. https://orcid.org/0000-0001-9156-

6971, agustin.delaherran@uam.es

(ii) Instituto Federal de São Paulo - IFSP, Itapetininga, SP, Brasil. https://orcid.org/0000-0002-1870-

7528, ivanfrt@yahoo.com.br

\begin{abstract}
:
This essay could also have been titled: "What if teacher training was radically disoriented?" It is part of other broader question: "What if our education and Pedagogy were radically wrong?". In its content, the authors' arguments are presented with the aim of expressing possible insufficiencies of teacher training and, therefore, of Didactics, as a science of formation by antonomasia. It is presented the possibility that it prevailed in education and training a general bias towards the outside and consequently a deficit of radical attention, and it is an imperative refocusing completely the teacher training. In the following lines they are condensed over two decades of observations in this regard. From a methodological perspective it will proceed with a dialectical and hermeneutical orientation supported by the "radical and inclusive training approach", from which critical arguments with a constructive purpose will be offered. After responding to the target, the work offers an alternative model of training, bringing in new development to pedagogical knowledge in a relevant subject for researchers and teaching professionals.
\end{abstract}

Keywords: teacher education, reflection, teaching practices, consciousness raising

\footnotetext{
${ }^{1}$ Bibliographic normalization: Leda Farah - farahledamaria@gmail.com

2 English version: Ivan Fortunato - ivanfrt@yahoo.com.br
} 


\section{Resumen:}

Este ensayo también podría haberse titulado: "¿Y si la formación del profesorado estuviese desorientada radicalmente?". Se inscribe en otra pregunta, más amplia: "¿Y si nuestra educación y la Pedagogia estwiesen radicalmente equivocadas?". En su contenido se exponen argumentos con el objetivo de expresar posibles insuficiencias de la formación del profesorado y, por tanto, de la Didáctica, como ciencia de la formación por antonomasia. Se presenta la posibilidad de que en educación y formación predomine un sesgo general hacia lo externo y, consecuentemente, un déficit de atención radical, deduciéndose el imperativo de reenfocar completamente la formación del profesorado. En las siguientes lineas se condensan más de dos décadas de observaciones en este sentido. Desde una perspectiva metodológica, se procederá con una orientación dialéctica y bermenéutica, apoyada en el "enfoque radical e inclusivo de la formación", desde el que se ofrecerán argumentos críticos con una finalidad constructiva. Tras responder al objetivo, el trabajo ofrece un modelo de formación alternativo, que aporta novedad al conocimiento pedagógico en una temática relevante para investigadores y profesionales de la enseñanza.

Palabras claves: formación de profesores, reflexión, práctica didáctica, concientización

\section{Introduction}

If we are honest with ourselves, perhaps we can observe that, frequently, in Didactics, in Spain and Brazil not even the scenarios of pedagogical renewal favor profound educational change. The first cause of this procedure is because we understand and approach change as an external phenomenon. The second, because the usual thing is that, instead of recognizing ourselves as conscious ignorant (a sort of Homo Sapiens ignorans) - as they were, for example, Confucius (1969), Buddha (1997), Socrates (cited in Plato, 1969), Newton (1686), Edison (cited in Josephson, 1959) or Einstein (2012) - we are convinced that we know we know (the action of Homo Sapiens sapiens). Maybe that's why the usual thing is that, professionals, researchers or readers, seek to listen or read in others, to reinforce their own thesis. Normally, approaches or reasons that are different or contrary to their own, instead of being celebrated or known, tend to be questioned, misjudged or rejected at the outset, with excuses and reasons that are not difficult to understand. The most common is that the receptive motivation is homeostatic and inertial and inclined to continue in the same state, to argue that 


\section{pro.posições}

http://dx.doi.org/10.1590/1980-6248-2017-0033

$e-I S S N$ 1980-6248

the desirable is already done, to preserve it and to justify the need for change, epistemological or professional. Exceptionally, novelties are tolerated and even appreciated, provided they are traced by authority figures prejudiced positively or towards whom hyperesthesia is experienced.

In Pedagogy in general and in Didactics in particular, we can observe a coherent set of convictions that are usually shared socially and professionally. From a scientific point of view, they form a consensual substratum, epistemologically hardened, that is hardly questioned. Its reason for being is to define a base on which to continue building, without the presence of uncomfortable doubt. This motivation is normal and understandable. But it associates a basic epistemic problem: with the flexibility, the self-criticism and the capacity for rectification practically lost, the pedagogical renewal and its necessary correspondence are not possible and they stay on the way. The formal effect is an incoherent Didactics, which has been able to lose, contradict or betray the spirit of the pedagogical renewal, although, from the point of view of the content it deals with, it does not concern itself with anything else, without being aware of it, by epistemological myopia or by deficient training of the person acting in this way, which responds to normality.

Precisely, the questioning of the unquestioned through the question "Why?" - referred to the obvious, the unquestioned or the invariant - is the prelude to fruitful creativity (Herrán, 2009b) and the atrium through which more knowledge Consciousness can happen to help evolve the science of teaching for education. With this impulse we could ask ourselves what is obvious in formation, what is not questioned, from this possible reorientation, radically doubt about it and try to advance in complexity of consciousness from a simultaneously scientific, artistic and technological scope such as Didactics, at the time, "core of Pedagogy" (Sevillano, 2011).

This essay is constructed in the light of the "radical and inclusive" approach to teaching formation (Herrán, 1995, 1997, 1998, 2003, 2005, 2011d, 2013, 2014, 2015, 2016a, 2016b, 2017a, 2017b, 2017c, 2017d), which suggests that Pedagogy and education develop in the visible part of the tree, in the emerged portion of the iceberg or in the near face of the Moon, and not therefore in the complexity and completeness of the being and the phenomenon. 


\section{pro.posições}

http://dx.doi.org/10.1590/1980-6248-2017-0033

$e-I S S N$ 1980-6248

From these epistemological referents, we will focus in this study on the possible radical disorientation of teacher training, from the questioning of two of its epicenters: reflection and practice, closely linked as a binary star. Specifically, we will try to give a critical and open answer to two questions: is it enough to reflect on the practice? And is practice the epicenter of training? The objective will be twofold: define the insufficiency associated with this double centering and deduce training alternatives.

\section{Is thinking about practice enough?}

Although the normal thing in Didactics is that most scientific references define the reflection on practice as a key to the optimization of teaching, we have questioned it. In fact, reflection is an insufficient practice to improve teaching and education (Herrán, 1999, 2014). According to the Royal Academy of the Spanish Language (2015), reflecting is thinking carefully and carefully about something. Reflection - attentive and thoughtful thinking about practice - can not change the teaching in depth. You can change surfaces, but not depth. For this reason, methodologies and actions based on reflection on action, such as research in the classroom (González \& Latorre, 2013), action research (Latorre, 2008, 2013), mentoring (Harvard Business School, 2004; Valverde, Ruiz de Miguel, García, \& Romero, 2004; Vélaz de Medrano Ureta, 2009) or reflective coaching (Rodríguez Marcos et al., 2011), or conceptions about the reflexive teacher such as those of Schön (1992) are insufficient, precisely for leaning on the reflection on the practice and perceiving as complete what is barely an external part of the phenomenon; For this reason, for example, action research does not generate profound changes in those who carry it out and leaves unpublished conditioning areas (Herrán, 2009a).

It follows that the dialogical reflection groups are limited a priori, because of their instrumental ambition and scope. For example, exposing points of view to incite reflection, provocation or mutual "stinging" (Zambrano, 2004, p.85) are not enough. The only possibility is self-training, which sometimes involves doing things that go beyond reflection: emptying one's existential self, deconditioning, disidentifying ones own point of view, losing bad practices lies in the "teaching ego" (Herrán, 2016a, Herrán \& González, 2002), meditate on the action or observe and observe without interpreting, without evaluating, etc. The previous 


\section{pro.posições}

$e-I S S N$ 1980-6248

http://dx.doi.org/10.1590/1980-6248-2017-0033

learning and the own knowledge can be constituted in "caverns" (Plato, 1969) external and internal and in the main difficulties for the learning, the conscience and the formation. As an intermediate step, it may make sense the radical change of the object of change in Pedagogy and Didactics (Herrán, 2013), which may have much more to do with who changes than with the changes or with its actions, at the time, effects all of them. For self-training, it is as important to incorporate as to lose and self-knowledge. It is lost in a formative situation when what is acquired has a greater degree of complexity of consciousness. If there is no loss, there is no gain, there is only loss of time or illusion of gain. Therefore, what it is sometimes is more to destroy to rebuild at another level of greater complexity. Reflection, in this context, is relevant to Didactics, if it is developed from a perspective of self-formation and deep observation of what one does as a teacher (Fortunato, 2016a), articulated in the consciousness.

Debate or dialogue is a complementary and incomplete action. Usually applied to the circumstantial. On training and its meaning there is little to discuss; Frequently, when it is debated, there is no unanimity or the content is not usually profound. On the one hand, training or education is not fully understood, because it is practiced with it a kind of educational exclusion: the "curricular exclusion" of challenges or radical issues, without which, simply, neither education nor education can take place. (Herrán, 2014, 2015). Being that way, how to long for it?

More than debating, it is about meditating, that is, observing and deepening to understand. Without depth there is no understanding. If you are not aware of the complex reality to which it refers, what is discussed and done may be correct, but superficial, insufficient. If in the training of teachers you have to discuss the school and all its complexity, it should not be done without knowledge of its reality. Therefore, we must observe it, but not forget its history (Fortunato, 2016b), nor synchronously, the deep radical variables on which its possible evolution may depend.

Another point that we must address is about training models and profiles and the role of the training advisor and the faculty. Teacher training takes place under or over models. Models are simplified schemes of what is perceived as a reality. "Simplification does not only mean limitation, it involves distortion" (Santos Guerra, 1999, p.103). Perhaps for these reasons Mayor Zaragoza (2000) said: "Let's stop giving models... The education system should be characterized by being in continuous evolution" (pp. 19-20). They are defined by their 


\section{pro.posıções}

$e-I S S N$ 1980-6248

http://dx.doi.org/10.1590/1980-6248-2017-0033

orientation to satisfaction, arrival, landing or results. They can serve to argue, to reflect. Nieto Díez says (1995) that: "Every 'model' has to be understood as a stereotyped abstraction of reality, a synthesis, a reduction that can not reflect a totality at all" [highlighted in the original] (p 39). We add that the models always include bias. Therefore, a model would be all the more valid the more unbiased. The infinitely complex would be totally unbiased, which would stop being a normal model:

the models that best represent the complex reality, in any case, are the simple ones. And the simple is not the easiest thing. The more simple and complex a model is, the less biased, the more open and the more interpretive power it will associate a priori. (Herrán \& González, 2002, p. 30)

The models also serve to compare. The comparison is based, intimately, on the concept/phenomenon of equality and identity. Equality does not exist in nature. Nothing is comparable to something in all its complexity, in the strict sense. Therefore, the comparison can only be cortical. This action may have its superficial interest, but it will not be radically useful. Neither the models nor the comparison makes sense when dealing with deep formation. What is built on both will be apparent, fictitious and counterproductive, if it is considered sufficient.

With a radical perspective, it does not make much sense to build profiles either. The profiles are contours, planes and external by definition. They neglect the inside. This disregard or negligence, in the strict sense, is a contradictio in terminis, if it is about training. The training is either deep or it is not training; it will be something else: practicing, competition, exercising... but not training. The training work from profiles is insufficient. Usually related to school models. To assume, for example, that the profile of the teacher depends on the model of school and education is a problem, because the premise is false and problematic a priori. It is for a general reason and several specific ones. The general reason or first problem is that it is a feigned obviousness. The most concrete reasons, which show their fallacious condition, are, at least, the following: 


\section{pro.posıções}

http://dx.doi.org/10.1590/1980-6248-2017-0033

$e$-ISSN 1980-6248

a) On the one hand, as already detailed, associating a profile with a teacher is like identifying a being with its silhouette or a person with his/hers skin.

b) Second, to equate school to model is to opt for a path as reassuring as impoverishing. It's like basing a medical treatment on a superficial diagnosis. It is not a correct procedure.

c) Third, because education can not be subordinated, in the first instance, to what is wanted.

Education is not and can not be an effect of a will. If education is not understood in all its depth, does an emotional, basically projective orientation (Freud, 1976) make sense from what is desired? Is this a reliable, precise yearning? It's stupid. In fact, it would seem that an indicator of incomprehension of education, in all its planes, is its association with interest, will and will, which are partially interpreted and often biased and manipulated. As it appears in the classic Zhuang zi (1996), it is like building a house following the opinions of those who contemplate it from the road. In what profession does this act?

Therefore, it makes little sense, therefore, to adapt the above to what society needs and demands. The egocentric society (Herrán, 2008, 2014, 2017b, 2017c) is structured on partial systems and interests. What he expresses that he requires does not usually coincide with his real needs. The most important educational needs are not perceived well, because they are radical: they are not evident, they do not depend on temporal, spatial, ideological or concrete circumstantial contexts, they are not included in official curricula nor in educational projects, they are key to training, because they nourish and they sustain the whole being, and they do not demand. It is infrequent that they are observed and claimed. Similarly, in the field of health, the doctor does not prescribe according to the occurrences of the patient.

But in education everything is done the other way around: on the one hand, the radical seems non-existent and the interest is external and externalizing. On the other hand, the de facto powers and users prescribe to the professionals what they have to teach, what they have to learn and what they have to learn, ignoring their reason and that of researchers and technicians with greater didactic or pedagogical knowledge. Finally, almost everything is about what is urgent, what is located and what is interpreted as socially and economically relevant, so that the fundamental reading for training, not evident or unclaimed, goes unnoticed and adjusts and enhances myopia. 


\section{pro.posıções}

$e$-ISSN 1980-6248

http://dx.doi.org/10.1590/1980-6248-2017-0033

Our option is inclusive with respect to some keys of the standard model (technicalreflexive-dialogical) that we can share. But it will not be an ordinary pattern with which to identify and apply or in which to act, but an approach from which to observe, with the phenomenon of redefined training. Presented in another way: the key is not only the seed, but also the bumus (consciousness, knowledge, society and evolution) and water. With a good substrate and water, any seed catches. If they fail, nothing lives, nor the best models.

Obviously when a continuous training model is required, it is constructed as a demand, that is, thought for others, in this case, for teachers. From our radical and inclusive pedagogical approach, this demand is contradictory. The only thing that can justify a demand like this is the training itself in the foreground, the training of those who demand, before imagining that of others. The classical pedagogue Confucius (1969) referred to coherence as a factor of formation when he expressed that the cultivated person first did things and then talked about them. This is very important among advisors and educators, because the opposite is to nourish the fascination and live on it as an udder that, rather than nurture, intoxicates whoever is breast fed.

Finally, therefore, we can not speak of Valencian, Brazilian, European or any other teacher, teacher or teacher models or profiles, community or university. This is absurd. Formation, education is not European, neither Spanish, nor Brazilian, nor Catholic, nor socialist, nor of any place or local, national or politically considered system. And if it is tinged with something, it will be partial and indoctrinating to some extent, with which it will be contradictory. There is nothing further from education and training than indoctrination. Our education and training acts as when healing a wound by sterilizing and soiling it at the same time. For this reason, we have concluded that nowadays, due to its biases, no educational system and no official curriculum can fully educate (Herrán, 2017b). Formation, if anything, is human, universal, educating and centered on the loss of ego and adult immaturity (both personal and collective), in consciousness, in self-knowledge, beyond personality (Herrán, 2004a), and in meditation, beyond reflection at the time the first didactic or formative methodology of history (Herrán, 2017a). 


\section{pro.posições}

$e-I S S N$ 1980-6248

http://dx.doi.org/10.1590/1980-6248-2017-0033

\section{Is the practice the epicenter of teacher formation?}

From the previous section it is inferred that it is not just a matter of reflecting or procuring models or profiles. Understanding that the cause of the improvement of teaching is reflection is tantamount to renouncing, from the outset, the interiorization, self-knowledge and meditation as ancestors and ancestral methodologies of deep education, with an appreciable experimental support, at least from the first Buddha (Buddha, 1997, Dōgen zenji, 1989, Marin, 1961, Nyanatiloka Mahathera, 1990, Osho, 2007, Pannikar, 1969, Rawding, 1991, Scott, 1998) and neurological (Muñoz, 2017, Palomero Pescador, 2011), known at least from the works of Tomio Hirai and other pioneers in the years 60-70, cited by Johnston (1980). It should be emphasized that both Buddha (1997) and Socrates (cited in Plato, 1969) point to self-knowledge as the great educational challenge. But that the sage of Athens, whose teachings are focused on knowledge, never explained how. However, Gautama Buddha is the great methodologist, the great pedagogue who aims at a formation beyond the mind and knowledge. Therefore, the West, Didactics and teacher training have followed Socrates, who, at the same time, has guided and limited, not only Pedagogy, but also Philosophy (Herrán, 2018).

Professional and personal development and teacher change require observing and becoming aware of the primary cause of teaching, as well as their knowledge and behavior. What does this mean? Let's think it the other way around. From the start, they are equivalent to not staying on its surface, nor to understanding that the surface is the depth. In a Chinese text of 1600 (cited in Yutang, 1961), the "Shi Chi Shuo" states: "In the vegetable world the stems grow upwards, and the roots do it downwards. But at no time does the plant stop nourishing itself and repairing itself "(p.59). The fragment is in accordance with the didactics of Lao zi (2006) or of Comenio (1984), which coincided in recognizing that nature is a source of teaching resources and, frequently, a teacher. In this case, this observation indicates that the stem is not the root, that the head is not the tail, nor the existential is the essential. This differentiation is basic for training.

Transferring to what concerns us, we deduce that knowledge or reflection on practice, knowledge or practice itself are not fundamental, in the strict sense, because they are effects or behaviors of those who generate them. They are not causal, they are not the center of the circumference, but their periphery. However, Popkewitz (2015), research professor of 


\section{pro.posições}

$e-I S S N$ 1980-6248

http://dx.doi.org/10.1590/1980-6248-2017-0033

curriculum and instruction at the University of Wisconsin (Madison, USA) and representative of the vanguard discourse of teacher training, states that: "The research of teaching practice and "Practical" / useful knowledge is fundamental for teachers and teacher training that deals with school change "[emphasis in original] (p. 428). This is the axis of Didactics as a normal science and, therefore, it is something that is not discussed, because it is considered good, as obvious, and therefore, it is accepted. For us, however, it is nonsense, for some reasons:

a) The discourse around practical knowledge - versus theoretical - fosters a duality that moves the observer or teacher away from an understanding of the educational phenomenon and of the formation based on complexity and consciousness.

b) How can what is related to practice be described as "fundamental", when it is, in a strict sense, a result or an effect, a professional behavior? What change do you mean? Is not that change a change in the realizations, an external change? It follows from this the existence of an internal dimension and the possibility of questioning the nature and profound meaning of educational change, with the help of a radical and inclusive approach to training (Herrán, 2013).

c) What is 'useful'? The little-known Nobel Prize for Literature in 1908, Rudolf C. Eucken (1925), wrote: "Always seek what is useful, said Aristotle, is not what best suits free and well-endowed men" (page 373). In a compatible line, the German pedagogue Müeller-Commichau (2016) criticizes utilitarianism in Didactics and Pedagogy. His arguments are that he does not fulfill the inheritance of Kant, Rousseau or Schiller. A Pedagogy of the present has the task of identifying the internal training resources of teachers and students to develop them. Ultimately - he says -, the Pedagogy and Didactics of the present is not a function of capitalism, but of a commitment to the total person of the student. We disagreed with the teacher Müeller on a crucial issue: the 'person' was what the ancient Greeks called disguise, hence 'personality'. The personality is the periphery of being, and is not unique, far from it. The Pedagogy and the Didactics that we try to update would have to do with the self-knowledge or the awareness of the essential being, and not only with the personality, nor with the practice. Being is the ignored center of the circumference of education, the axis of the plectonemic spiral of education. But we are waiting for the outline. How to long for a regular, reliable trajectory, if the compass is not well supported in its center? 


\section{pro.posıções}

http://dx.doi.org/10.1590/1980-6248-2017-0033

$e$-ISSN 1980-6248

Therefore, practice, reflection, personality, skills, competences, etc. they are eccentric, because they are, in a strict sense, relative externalities. Neither Kant, nor Rousseau, nor Schiller deepened enough, in this sense. Neither our great academics have done it, so that Pedagogy and Didactics seem to place their epistemological center of gravity in the drawing, rather than in the centering of the compass or in the being that drives it.

Later, Popkewitz (2015) bases its reasons by pointing out other obviedades that we criticize successively:

a) "The 'practice' is an abstraction about what the desired teacher should be" [emphasis in original] ( $\mathrm{p} 428$ ). This means that, in the strict sense and according to the author, what a teacher should be is his positive action and behavior. It's like ruling that an iceberg is only its visible part. It is, in our opinion, a partial reason and, therefore, very inaccurate, false.

b) "That kind of person is called 'professional', whose tasks are produced to change the others - the child, the family and the community." This approach incurs again in a fundamental mistake, that in a previous work (Herrán \& González, 2002) we define as "error number 1 of the Didactics". It refers to the tendency to surround oneself, to bypass with oneself, to deal with others and all kinds of issues, systematically and de facto disregarding their own formation. That is, bypassing one's self-training (Gadamer, 2000).

This approach, these theses and this author are discussed little or nothing in Didactics. They are practically axiomatic. However, they are radically wrong, and it is not difficult to see: it only requires will and activate a different look. The root of teaching is not practice. The practice is an effect of a previous source. The root of the teaching is not the previous action or reflection, simultaneous or subsequent, that moves or motivates it. It is not the teacher's thought, nor his personality, nor his educational action. They have never been, although in the so-called "scientific literature" hardly read anything else. Thinking like this, perimetrically, these theses never hit the mark. However, these contributions-echo and recurrent until the tedium, are recognized as if they were targets. 


\section{pro.posições}

e-ISSN 1980-6248

http://dx.doi.org/10.1590/1980-6248-2017-0033

The root of the teaching has more to do with who performs the practice, with whom they think, with their conscience and teaching ego. The reflection on the practice is an action on a cortical effect (the exterior of the interior). It has little to do with the interior of the interior, with the essential being, which in turn has nothing to do with the above.

An access to the interior would require a kind of meditation - not mindfulness (Herradas, 2017) -, preceded by an analytical inquiry with a radical and inclusive orientation, that is, non-dual, non-partial, integrative or total. Among other factors, it would require influencing each teacher and their institution from several points of view: awareness, personal and institutional maturity and malpractice generated by personal egocentrism, teams, groups, institutional or systemic in general (Herrán, 2016a), base and effect of the society of immaturity that saturates all systems (Herrán, 2004b, 2011a, 2011b, 2014).

The interior is not accessed by reflection, and less if it is applied to practice. This is the first thing that, from our approach, should be considered. With this reorientation other actions are required that can be key for a formative internalization, beyond - or more here, in a strict sense - of reflection:

a) First and foremost repair who thinks and in their nature, not in the content of thought, its action, its emotions, its personality, not even in oneself as an object subject of itself.

b) Become aware of what is not seen, of what is not thought, of what remains to be known: "knowing that you do not know what you do not know" (Confucius, 1969).

c) Detect what is left over, what weighs down. Focus efforts on the dissolution of the aggregate, in the elimination or loss. Stop identifying training only with learning or acquiring knowledge, that is, with accumulation, and adding loss or resignation as a key aspect. In his case, to renounce "until the most certain and wanted" (Dewey, 1989), a practice quite unusual in the initial and continuous formation of the teachers, hardly updated and less practiced of the American pedagogue. Empty the own garbage deposit -composed by an amalgam of prejudices, predispositions, partialities, falsehoods, conditioning factors, inertia, identifications, personal and social mental programming, convictions, certainties, assurances, quietudes, etc.- It is that the conscience that gives knowledge rise in complexity, first, on itself, the formation itself 


\section{pro.posıções}

http://dx.doi.org/10.1590/1980-6248-2017-0033

$e-I S S N$ 1980-6248

and its conditioning factors, and on the phenomenon of teaching for training afterwards, to focus and not indoctrinate when teaching.

d) Internalize and seek self-knowledge as the true axis of formation (Herrán, 2004a), as coincidentally and at the same time taught by Buddha (1997) and Socrates (cited in Plato, 1969), the great masters of the East and the West, respectively. Observe that the Socrates path is centered on knowledge and has served as the basis for a Pedagogy based on knowledge, which is ours. And that the way of Buddha is centered on not knowing, that except for exceptions (Anonymous English of the XIV century, 1981; Eckhart, 1988), the West has not followed. From the radical and inclusive approach and despite being in the society of ignorance, rather than in knowledge, both are complementary (Herrán, 2018).

\section{Discussion}

The predominant teacher training approach is that of reflective, dialogical and practice-focused teacher (Day, 2005, 2006, Day \& Sachs, 2004, Dewey, 1971, 1975, 1989, 2008a, 2008b, Fendler, 2003, Schön, 1992, 1998, 2002). Nuclearly refers to the one that is based on three kinds of reflection: in action, on reflection in action and on the analysis and description of the total process of reflection (Iranzo, 2012; Schön, 2002). From an objective, epistemological point of view, with the history of educational innovation as a frame of reference, it is striking that consciousness, self-centeredness, meditation or self-knowledge, in a pedagogical or formative sense (Herrán, 2004a, 2014), are not part of the basic educational field of a teacher (Herrán, 1995).

This is indeed what happens, judging by the predominant orientation of teacher training, directed to practice. As Rodríguez Marcos et al. (2011) and Rodríguez Marcos y Pessoa (2011), both the professor and his professional community use reflection in two closely interrelated planes: the individual and the cooperative, associable to professional and formative dialogue. The individual can be developed through effective and contrasted instruments, such as action research (individual), the didactogram, the reflective diary, etc. The cooperative includes valuable methodologies such as action research, mentoring or reflective coaching. 


\section{pro.posições}

$e-I S S N$ 1980-6248

http://dx.doi.org/10.1590/1980-6248-2017-0033

The meaning of this formation is valid and necessary, but partial. It is valid for what it attends: reflection, action, experiences, evaluations and even for the teaching personality in the professional context. But it is useless for what it does not perceive and that is the cause of the previous thing: the teaching conscience, its egocentric, personal and social conditioning, the teachers' maturity and immaturity, the being of the teacher, the self-knowledge, etc. It does not cover the whole person or the entire teacher. Try to transcend the teacher routinized, mechanical, impulsive etc. But, from our point of view, they do not reach full formation, because neither reflection, nor the foundation of action, nor competent teaching necessarily root in mature and conscious practice, not only personal or team, but also organizational. or institutional (Herrán, 2011a, 2011b). Neither does it lead to collaboration, dialogue, being part of a learning community, the participation of good critical friends, research on the teaching practice itself, teaching practice based on theories of teaching, research in didactics, the significant and fruitful relationship between theory and practice (Rozada, 1997), research for innovation and improvement of teaching (Medina, 2009, Perrenoud, 2012a, 2012b, Sevillano, 2007), competency-focused training (Arnold , 2012, Bisquerra, 2007, Bolívar, 2008, Pérez Pueyo, 2013). For example, in this sense, Savater (1997) wrote that society does not need both competent persons and complete persons. That is why we have observed that a competencybased education -or in any of the previous pedagogical actions- is a pedagogical contradiction (Herrán \& Álvarez, 2010).

Unlike the one proposed by Day (2006, p.44) and the main currents of Didactics, the performance of the reflective professional is not synonymous with good practice at all. Reflection is not enough to improve the practice (Herrán, 1999), nor does it guarantee profound changes in teaching (Herrán, 2011c, Ramírez \& Herrán, 2012). Professional development and teaching change require observing and becoming aware of the root of education and training, as well as its periphery. The deep improvement (from its root) of the practice can include concrete radical challenges such as educational and teaching malpractice and the consequent ego-centered teaching and institutional 'performance' (Herrán, 2016a) and require focus on evolving consciousness towards self-knowledge, via knowledge (acquisition of learning), but also via formative losses (deconditioning, disidentification) and complexityawareness, both of the reflective teacher and of his team, center and students. Consciousness includes reflection and research on practice, but it does not stay in it. It also includes these and other radical formative constructs, inaccessible via reflection, research, innovation or 


\section{pro.posições}

$e-I S S N$ 1980-6248

http://dx.doi.org/10.1590/1980-6248-2017-0033

conventional or normal changes, as proposed by the model of reflective and dialogical practical training. This approach can be useful to investigate the practice alone or accompanied or for limited and external improvements in teaching. Sometimes this will be enough. But not others. It is meager, but above all, it does not refer to the teacher education center.

As a consequence of the above reasons, we disagree with other generally accepted lines of reason that subordinate the change in practice to the "transformation of the understanding" (Gimeno Sacristán, 1998, p. 128). We question this thesis, tacitly assumed, because the change of understanding does not always bring change in practice. In fact, although many didactic problems often begin with erroneous thoughts, teacher thinking is part of their internal exteriority. Sometimes the change in practices requires a change in consciousness applied to one's own "ego" and an appropriate behavior -for example, linked to the abundant malpractice (mala praxis) egotistical teacher (Herrán \& González, 2002). In fact, it may happen that, even if you understand what is desirable, not only do you not change or do you want to change, but you do not want to change. In short, since not all crows are black, cognitive and emotional change are not always enough. In fact, they are almost never enough and, often, in the most necessary cases. If they were enough, the professors and professors of Didactics, who understand very well these and other reasons, would be exemplary, teachers, both with students and with colleagues. Maybe some of them are.

\section{Approach}

Teacher education that satisfies the criticisms and proposals made can be represented in at least two modes or geometric models: one triangular and one tetrahedral. The first is based on the concept of "total formation" or holistic (Herrán, 1999), symbolized by a scalene triangle, of vertices (figure 1):

a) The technical-reflexive training, centered on the imperative of acquiring well-founded and functional professional knowledge, through analysis and dialogue. It would equal the current training. 


\section{pro.posıções}

http://dx.doi.org/10.1590/1980-6248-2017-0033

$e$-ISSN 1980-6248

b) The self-evaluation of self-centeredness and its scope in teaching as a source of bad practice, in one's professional and personal development and in personal relationships, to develop the possibility of learning to perform and recognize conditioning factors, limitations and other burdens - both of itself as equipment, organs, institution or education induced by curricula, national education systems and international organizations-, to lose them, to free themselves and improve.

c) The applied consciousness, oriented to learn to evolve, mature and be more educated in the classical Greek sense, that is, more teachers.

The center of the triangle would be occupied by humility or consciousness of ignorance, serenity, meditation (observation), the will to inquire, to investigate, to internalize and evolve from egocentrism to more advanced and lucid states of consciousness or mentality (Herrán, 2006, 2009a).

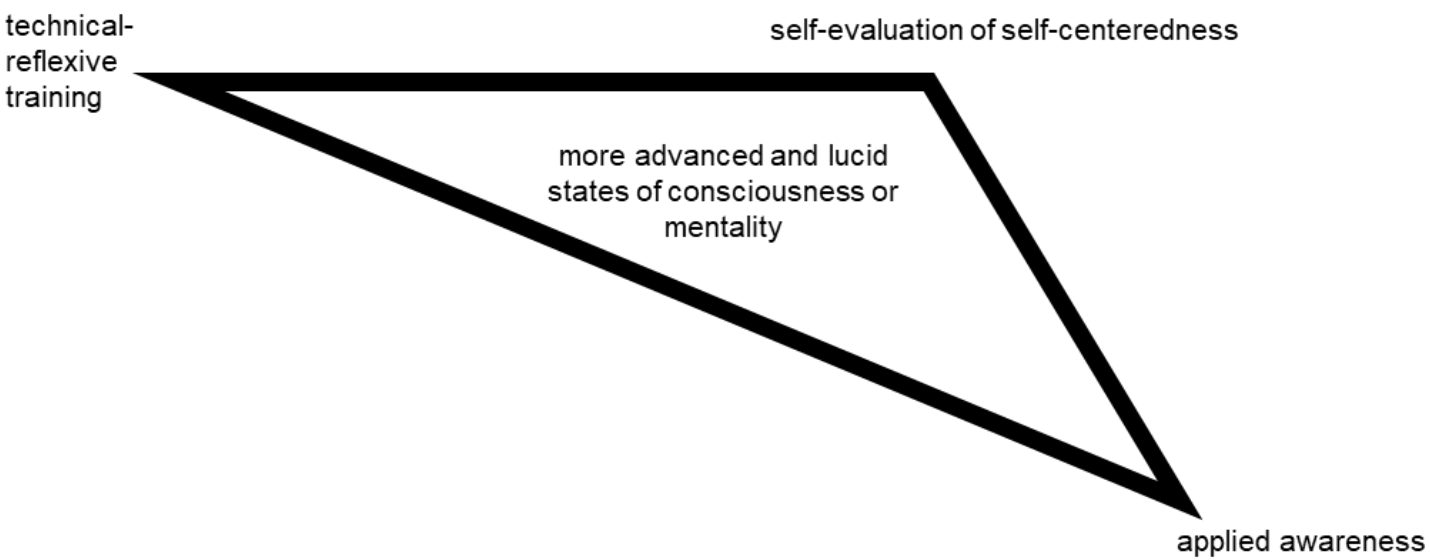

Figure 1. Focus on radical and inclusive teacher education (triangular model) Source: Herrán (1999) (adapted)

The second is this tetrahedral, which was shared in a meeting with pedagogical advisers from Valencia ${ }^{3}$ (figure 2), whose vertices would be:

a) The technical-reflexive training.

b) The egocentrism and the teaching, institutional and systems malpractice in general..

\footnotetext{
${ }^{3}$ Herran participated in the meeting with training advisors, held in January 2016, within the framework of the CEFIRES Education Advisors Training Days (Center de Formació, Innovació i Recursos Educatius) of the Valencian Community.
} 
c) Applied consciousness (stages of evolution in complexity of consciousness).

d) Self-training in the other "radical issues" (key challenges for training, independent of contexts and not demanded). For example, universality, death, humanity, barbarism, prenatal education, internal and external poverty, etc.).

The center of the tetrahedron would be occupied by meditation and observation generated from a conscious state.

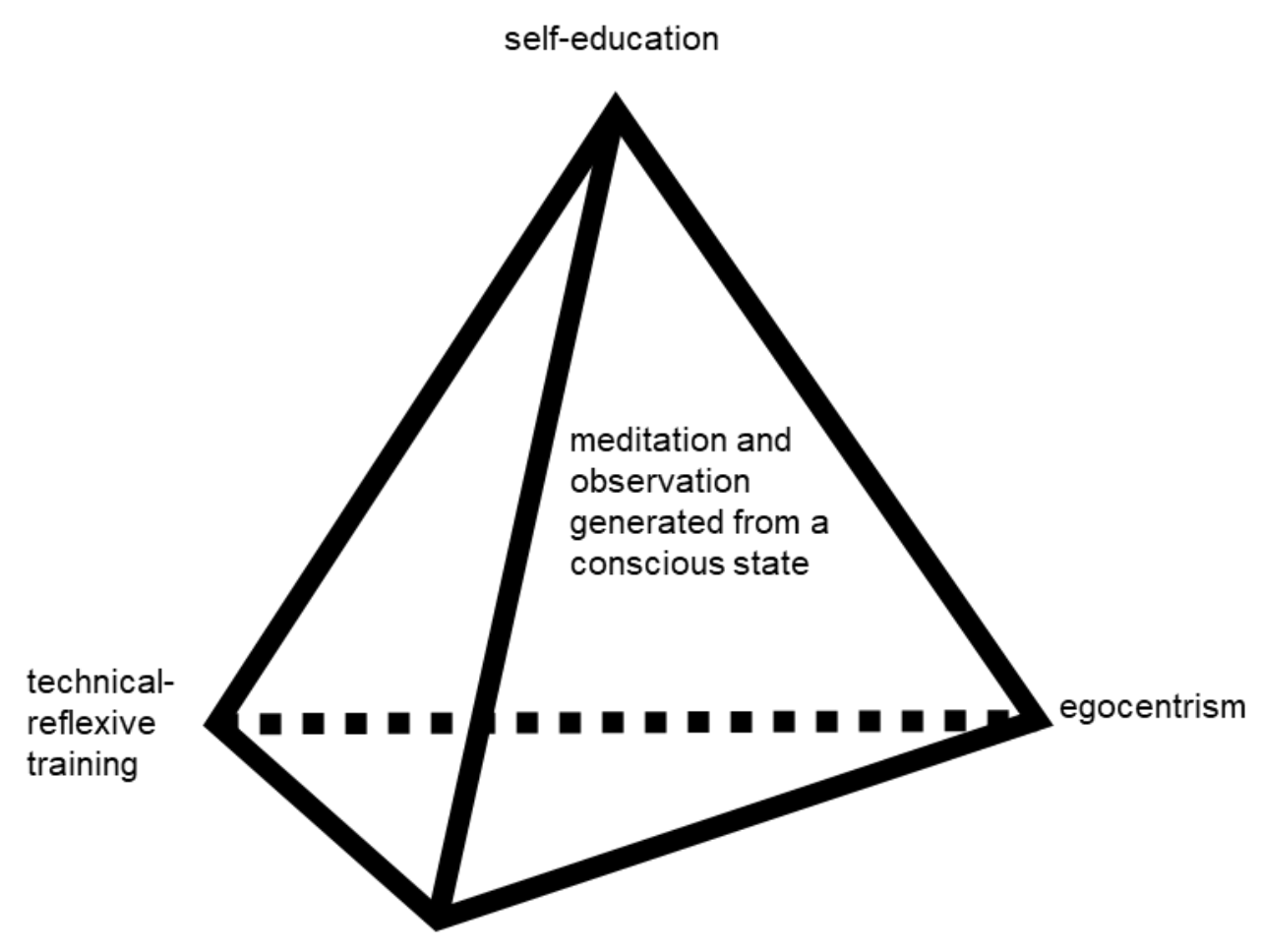

applied awareness

Figure 2. Focus on radical and inclusive teacher education (modelo tetrahedral)

Fuente: Herrán (2014) (adapted) 


\section{pro.posıções}

http://dx.doi.org/10.1590/1980-6248-2017-0033

$e$-ISSN 1980-6248

\section{Conclusion}

The text was drafted to share the possibility that in education and training almost everything that is being done is radically wrong, although externally it is not or it does not seem so (Herrán, 2007b). The exposition of reasons was based on the observation of education during twenty-four years, carried out from a concrete pedagogical approach, called first "complex-evolutionist" (Herrán, 2003) and then "radical and inclusive" (Herrán, 2014). This perspective, contrasted and validated through dozens of publications in demanding media and half a dozen doctoral theses, defines unique topics and allows to appreciate relatively unusual problems. The one of this work has been the critic to the normal approach of formation of profesorado, like axis of normality in the Didactics.

What has been observed and exposed is a serious epistemological problem, underlying the normality of Didactics itself and that, apparently, is not interpreted as a radical object of change. In short, reductions and half-truths are identified (therefore, falsehoods, if taken for certain), which are assumed without relevant questioning by the scientific community. Some of them, necessary but insufficient, are:

- the univocal and appropriate identification of the teacher as a reflective professional (Perrenoud, 2012b; Zeichner, 1993), instead of a professional in a conscious state;

- the narrow association between reflection, thought and action or reflective practice (Rodríguez Marcos \& Pessoa, 2011; Schön, 1998), instead of an action based on internalization, consciousness, professional maturity, egolessness (immaturity, conditioning, attachment, etc.), universality, broad mind, doubt, humility, etc.;

- the theory-practice duality as the basis of training and didactic change (Popkewitz, 2015), instead of a dialectical synthesis overcome via complexity of consciousness;

- the identification between myopic "complexity" (pseudo-complexity) and more of the same (read, reflective practice as the basis for teacher training) (Jay \& Johnson, 2002), rather than destruction of certainties or decongestion of recurring traffic jams for the fluency of Teaching and Pedagogy as evolving sciences; 


\section{pro.posıções}

http://dx.doi.org/10.1590/1980-6248-2017-0033

$e-I S S N$ 1980-6248

- the link between teacher preparation for a changing world and learning, thought and action (Darling-Hammond \& Brandsford, 2005), instead of deep or full training to change life from awareness, elimination and meditation, in addition to from learning and knowing, etc.

In short, when it is reviewed and repaired in the training of reflective teachers from the point of view of a pedagogical field in construction or in dispute (Ruffineli, 2017), there is no self-criticism towards the approach itself at all, nor in terms of bias, neither in terms of incompletion, nor in terms of insufficiency. In fact, it is not read or seems to be repaired in the possibility that centering the training in the teaching reflection on the practice can be, overall, an error, that there are other possibilities, that the formation's vein could be elsewhere , or that the extraction technique of the mineral could be another, so that this normal perspective is refutable and completable from broader and deeper coordinates that were already pointed out in the past, specifically in India and China of the centuries -VI and - V.

It has been possible to translate and articulate the didactic diagnosis with an applied proposal, which has taken the form of two geometric models, simple and complex at the same time. They have resulted from the complementarity between the normal approach of Didactics for teacher training and the inclusion of radical challenges of education (personal egocentrism, systems, collective, etc., consciousness, self-knowledge, meditation, maturity personal, professional and institutional, Humanity, etc.), without which it is not possible to speak of education or full training of teachers, or any other person, in the formal or nonformal.

With a focus only practical reflection can not long for profound changes in teaching, because to focus on itself or the teacher's reflection as a researcher of their action, leaves unattended broad areas of training without which this desire, simply, is not possible. If the radical challenges are excluded from the formation, they are covered up in the Pedagogy or they are ignored de facto in Didactics, it is not that they are committing an outrage; is that these sciences will develop in error and, therefore, everything that is done from them with a formative purpose, will be wrong. Applying this reason to what concerns us: reducing the training of teachers to a superficial or obvious level assimilable to effects and results would be equivalent to identify a person with its appearance. 


\section{pro.posições}

http://dx.doi.org/10.1590/1980-6248-2017-0033

$e-I S S N$ 1980-6248

The improvement of teaching based on reflection on practice and on the transformation of understanding today is little discussed. From our perspective, they define an approach that supports limited actions for a notion of teaching change biased a priori towards the surface. Sometimes, in fact, it is useless. Sometimes, this transformation of the understanding is so insufficient and ineffective that it borders on self-deception or farce. In these cases, the investigator or the advisor may be false accomplices, very cynical, if they know they are lying, very ignorant, if they do not know it. We see again and again that, far from bad intentions, what happens is that simply the depth of the formation is ignored. Missing steps in complexity-consciousness, beyond bias.

The other day we asked a relevant innovator who gave a lecture at my faculty. At the end of his speech, in congratulations, I assured him that his contribution, which he already knew, was interesting and that it was biased. I deduced that this expert saw well, but only up close. How is it possible not to recognize, with certainty, that a project is biased a priori, when the river of Teaching and Normal Pedagogy, in which it flows, is also biased? It is like saying that your thesis is fallible, how to communicate to someone who is finite and who is going to die: they are not critical, they are observations and constituent qualifiers, they do not have to bother anyone, because things can not be otherwise. It is the egos that take for granted, those that feel hurt, those that may need to react, counterattack. What fear is there in doubting and recognizing that, due to our limitations and the biases of everyone - also, of course, of those who write - if we converge we can rise in knowledge and in conscience, if and only if our formation is good and radical and that's why one can transcend the ego?

Today the formation is like the Moon: we always see the same face. This phenomenon occurs normally in education, when referring to the educational and formative change: although it is said that they are re-considered, that they are redefined, that they are revised for example, Delors (1996), Domínguez and Feito (2007), Esteve (2003), Fullan (2002), García Garrido (1986), García, Gozálvez, Vázquez y Escámez (2010), Gimeno Sacristán (2005, 2013), Mayor Zaragoza (2009), Medina (2009), Monarca (2009), Morin (2001) , 2009), Popkewitz (2000, 2009), Torres Santomé (2007), etc.- there are no radical, internal differences. Vision changes are external, and are adopted as paramount. But the Moon is not even the union between its near and far part: it is much more than what can be defined by its surface: there is another internal reality in the satellite. Consequently, the profound change in practice requires a different approach, "a change of change" in Didactics and not normalized in 


\section{pro.posıções}

$e-I S S N$ 1980-6248

http://dx.doi.org/10.1590/1980-6248-2017-0033

Pedagogy. Although it is not strictly comparable, there are precedents in the History of contemporary educational innovation that we can look at. One example is the "change of shift" presented by Celestin Freinet, although its pedagogy is ignored in training programs (Fortunato, 2016c).

Although much is said and published about it, today the full training of teachers is an unreality, a chimera, a scam. The recognition of the phenomenon could be an act of conscience, of scientific maturity, that perhaps already has something to do with the solution of the radical educational deficit. His denial, on the other hand, could be equivalent to the egocentric attitude of a doctor who does not recognize that his therapy does not cure.

In this situation, what is the initial problem of teacher training -and of educators, in general-? It could be concluded that there are three: one of focus, another instrumental and another assimilable to the ego:

- The focus is that the first thing to note is that the radical problem is not "the formation of teachers", nor "of the Didactic": rooted in each, because, by virtue of the "theory of default" (Herrán, 2015, 2016b, 2017b), each consciousness is the true center of the reality that observes and in which it transcends.

- The instrumental problem is not so much that the well is too deep: the rope is too short. The reflection on the practice, for example, is a rope that does not reach the bottom of the well, just scratches the surface of the water. Therefore, why not change it for a longer one?

- The third has to do with what we once called the "caballito effect" of carousel (Herrán, 1997). It has to do with clinging and not wanting to get off the carousel, as some young children do at fairs. But this procedure is also very normal for adults. For example, it is common in all sciences. But its possible evolution - and not only its development, which may be biased and does not have to be positive - will depend on disidentification, deconditioning and getting off attraction, to allow events to progress.

The formal differences between the proposed approach and the questioned model are of focus and depth, and are specified in the radical constructs accessible via internalization, deconditioning and meditation, which are not accessible via reflection. When reflection is used 


\section{pro.posıções}

$e-I S S N$ 1980-6248

http://dx.doi.org/10.1590/1980-6248-2017-0033

for what does not work, it can generate illusions of change, professional fiction, social hypocrisy and a kind of pedagogical falsehood. This is why the inverse phenomenon can also occur: there will be authors who maintain that everything exposed in this essay is already done.

When the training of teachers - and by extension, of educators - is observed from a total approach to training, what is found is that there is an unknown field that sustains and nourishes the external; that reflection and action are part of that superficial and necessary world, and that the key to formation is not even in consciousness, but in the harmonious, complex and conscious inclusion of the exterior and the interior.

It is not possible to fly with only one wing, nor to examine the horizon with myopia. Without depth there is no horizon. The sea is not its swell. What is the point of ignoring that your measurement is completely ignored? What science, what profession, what professionals opt a priori for the short?

Else. It is true that the quality of the apples justifies the existence of the apple tree. But the results do not depend on themselves. They depend on the ecosystem and the roots of your tree. Focusing only on them is equivalent to not understanding anything. The essential thing, paraphrasing Lao zi (2006), is that in fruits there is interest, but in the roots there is utility. The useful thing, in addition to nourishing and sustaining the tree, is what is vital. In contrast, the apple is not essential for the plant.

\section{References}

Anónimo inglés del siglo XIV. (1981). La nube del no saber y El libro de la orientación particular. Madrid: Paulinas.

Arnold, R. (2012). La importancia de las competencias emocionales en la educación superior. In J. Paredes (Coord.), Innovación de la Enseñanza. Seminario Permanente IUCE-UAM. Universidad Autónoma de Madrid, Madrid. 


\section{pro.posıções}

http://dx.doi.org/10.1590/1980-6248-2017-0033

$e-I S S N$ 1980-6248

Bisquerra, R. (2007). Las competencias emocionales. Educación XXI, 10, 61-82.

Bolívar, A. (2008). Ciudadanía y competencias básicas. Sevilla. Fundación ECOEM.

Buda (1997). Dhammapada o las enseñanzas de Buda. México: FCE.

Comenio (1984). Didáctica magna. Madrid: Akal.

Confucio (1969). Los cuatro libros de Confucio. Madrid: Bergua.

Darling-Hammond, L., \& Brandsford, J. (2005). Preparing teachers for a changing world: What teachers should learn and be able to do. San Francisco: Jossey-Bass.

Day, C. (2005). Formar docentes. Madrid: Narcea.

Day, C. (2006). La pasión por enseñar: La identidad personal y profesional del docente y sus valores. Madrid: Narcea.

Day, C., \& Sachs, J. (Eds.). (2004). International handbook of the continuing professional development of teachers. Berkshire (England): Open University Press.

Delors, J. (Coord.) (1996). La educación encierra un tesoro. Madrid: Santillana/UNESCO.

Dewey, J. (1971). Experiencia y educación. Madrid: Biblioteca Nueva.

Dewey, J. (1975). Democracia y educación. Madrid: Morata.

Dewey, J. (1989). Cómo pensamos. Nueva exposición de la relación entre pensamiento y proceso educativo. Barcelona: Paidós.

Dewey, J. (2008a). El arte como experiencia. Madrid: Morata.

Dewey, J. (2008b). La teoría de la valoración. Madrid: Siruela.

Dōgen zenji (1989). Shōbōgenzōò (La naturalez̧a de Buda). Barcelona: Obelisco.

Domínguez, J., \& Feito, R. (2007). Finalidades de la educación en una sociedad democrática. Madrid: Octaedro.

Eckhart, M. (1988). Maestro Eckhart: obras escogidas. Barcelona: Edicomunicación.

Einstein, A. (2012). El mundo como yo lo veo. Madrid: Brontes. 


\section{pro.posıções}

http://dx.doi.org/10.1590/1980-6248-2017-0033

$e-I S S N$ 1980-6248

Esteve, J. M. (2003). La tercera revolución educativa: la educación en la sociedad del conocimiento. Barcelona: Paidós

Eucken, R. (1925). La lucha por un contenido espiritual de la vida. Nuevos fundamentos para una concepción general del mundo. Madrid: Daniel Jorro.

Fendler, L. (2003). Teacher reflection in a hall of mirrors: Historical influences and political reverberations. Educational Researcher, 32(3), 16-25.

Fortunato, I. (2016a). Ensinando futuros professores sobre literatura infantil: relato de experiência. ETD - Educação Temática Digital, 18(2), 710-718.

Fortunato, I. (2016b). Ainda é preciso ter cuidado: escola?!. InterScience Place, 11(2), 86-95.

Fortunato, I. (2016c). 50 anos sem Célestin Freinet, 500 anos de retrocesso das práticas escolares. Journal for Educators, Teachers and Trainers, 7(1), 174-181.

Freud, A. (1976). El yo y los mecanismos de defensa. Buenos Aires: Paidós.

Fullan, M. (2002). Los nuevos significados del cambio en la educación. Barcelona: Octaedro.

Gadamer, H. G. (2000). La educación es educarse. Barcelona: Paidós.

García Garrido, J. L. (1986). Problemas mundiales de la educación (2a ed.). Madrid: Dykinson.

García, R., Gozálvez, V., Vázquez, V., \& Escámez, J. (2010). Repensando la educación: cuestiones y debates para el siglo XXI. Valencia: Brief.

Gimeno Sacristán, J. (1998). Poderes inestables en educación. Madrid: Morata.

Gimeno Sacristán, J. (2005). La educación que aún es posible. Madrid: Morata.

Gimeno Sacristán, J. (2013). En busca del sentido de la educación. Madrid: Morata.

González, R., \& Latorre, A. (2013). El maestro investigador. La investigación en el aula. Barcelona: Graó.

Harvard Business School (2004). Coachingy mentoring. Bilbao: Deusto. 


\section{pro.posıções}

$e$-ISSN 1980-6248

Herradas, S. (2017). En el aula... ¿meditación o mindfulness? Boletín del Ilustre Colegio Oficial de Doctores y Licenciados en Filosofía y Letras y en Ciencias de Madrid. Apuntes de Pedagogía (269), 14-15. Recuperado em 4, junio, 2017, de https://www.cdlmadrid.org/wpcontent/uploads/2016/02/pedagogia0617.pdf

Herrán, A. de la (1995). Ego, autoconocimiento y conciencia: Tres ámbitos en la formación básica y la evolución personal de los profesores. Madrid: Universidad Complutense de Madrid. Recuperado 15, febrero, 2017, de http://eprints.ucm.es/tesis/19911996/S/5/S5007801.pdf

Herrán, A. de la (1997). El ego humano. Del yo existencial al ser esencial. Madrid: San Pablo.

Herrán, A. de la (1998). La conciencia bumana. Hacia una educación transpersonal. Madrid: San Pablo.

Herrán, A. de la (1999). Claves para la formación total de los profesores. Tendencias Pedagógicas (4), 37-58. Recuperado em 15, febrero, 2017, de http://radicaleinclusiva.com/wpcontent/uploads/2018/01/clavesformtot.pdf

Herrán, A. de la (2003). El nuevo paradigma complejo-evolucionista en educación. Revista Complutense de Educación, 14(2), 499-562. Recuperado em 15, febrero, 2017, de http://revistas.ucm.es/index.php/RCED/article/view/RCED0303220499A

Herrán, A. de la (2004a). El autoconocimiento como eje de la formación. Revista Complutense de Educación, 15(1), 11-50. Recuperado em 15, febrero, 2017, de http://radicaleinclusiva.com/wpcontent/uploads/2018/01/autoconocimientoyformacion.pdf

Herrán, A. de la (2004b). Teoría de los sistemas evolucionados: hacia las organizaciones que maduran. Tendencias Pedagógicas, (9), 71-109. Recuperado em 15, febrero, 2017, de http://radicaleinclusiva.com/wp-content/uploads/2018/01/TSE.pdf

Herrán, A. de la (2005). El nuevo "paradigma" complejo-evolucionista en educación. In A. de la Herrán, E. Hashimoto, \& E. Machado, Investigar en educación: fundamentos, aplicación y nuevas perspectivas (pp. 481-571). Madrid: Dilex. Recuperado em 15, febrero, 2017, de http://radicaleinclusiva.com/wp-content/uploads/2018/01/paradigmac-e.pdf 


\section{pro.posıções}

http://dx.doi.org/10.1590/1980-6248-2017-0033

$e$-ISSN 1980-6248

Herrán, A. de la (2006). Los estados de conciencia: análisis de un constructo clave para un enfoque transpersonal de la Didáctica y la formación del profesorado. Tendencias Pedagógicas (11), 103-154. Recuperado em 15, febrero, 2017, de http://radicaleinclusiva.com/wp-content/uploads/2018/01/EC.pdf

Herrán, A. de la (2008). Hacia una educación para la universalidad: más allá de los ismos. In J. Valle (Coord.), De la identidad local a la ciudadania universal: el gran reto de la educación contemporánea (pp. 209-257). Bilbao: Fundación para la Libertad-UAM. Recuperado em 15, febrero, 2017, de http://radicaleinclusiva.com/wpcontent/uploads/2018/01/haciaunaeduniv.pdf

Herrán, A. de la (2009a). Estadios de evolución docente. Tendencias Pedagógicas (14), 375-415. Recuperado em 15, febrero, 2017, de http://radicaleinclusiva.com/wpcontent/uploads/2018/01/estadiosevol.pdf

Herrán, A. de la (2009b). Técnicas didácticas en la práctica de la creatividad formativa. In J. Paredes, A. de la Herrán (Coords.), La práctica de la innovación educativa (pp. 135-160). Madrid: Síntesis.

Herrán, A. de la (2011a). Indicadores de madurez institucional. Revista Iberoamericana de Estudos em Educaşão, 6(1), 51-88. Recuperado em 15, febrero, 2017, de http://radicaleinclusiva.com/wpcontent/uploads/2018/01/madurezinstitucional2.pdf

Herrán, A. de la (2011b). La madurez institucional como constructo pedagógico. In E. Sebastián Heredero, \& M. Martin Bris, Transferencia del conocimiento a partir de prácticas educativas en los contextos español y brasileño (pp. 145-163). Alcalá de Henares: Universidad de Alcalá. Recuperado em 15, febrero, 2017, de http://radicaleinclusiva.com/wpcontent/uploads/2018/01/madurezinstitucional2.pdf

Herrán, A. de la (2011c). ¿Más allá del profesor reflexivo y de la reflexión sobre la práctica? In A. Medina, A. de la Herrán, \& C. Sánchez (Coords.), Formación pedagógica y práctica del profesorado (pp. 117-152). Madrid: Ramón Areces. Recuperado em 15, febrero, 2017, de http://radicaleinclusiva.com/wp-content/uploads/2018/01/masallaprofreflex.pdf 


\section{pro.posıções}

http://dx.doi.org/10.1590/1980-6248-2017-0033

$e$-ISSN 1980-6248

Herrán, A. de la (2011d). Reflexiones para una reforma profunda de la educación, desde un enfoque basado en la complejidad, la universalidad y la conciencia. Educación XX1, (14), 245-264. Recuperado em 15, febrero, 2017, de http://www.redalyc.org/pdf/706/70618224011.pdf

Herrán, A. de la (2013). Reflexiones sobre el cambio del cambio en Pedagogía: un enfoque radical. Matices del Posgrado Aragón (20), 108-133. Recuperado em 4, febrero, 2017, de http://radicaleinclusiva.com/wp-content/uploads/2018/01/cambpedagradical.pdf

Herrán, A. de la (2014). Enfoque radical e inclusivo de la formación. REICE - Revista Iberoamericana sobre Calidad, Eficacia y Cambio en Educación, 12(2), 163-264. Recuperado em 4, junio, 2017, de http://www.rinace.net/reice/numeros/arts/vol12num2/art8.pdf

Herrán, A. de la (2015). Pedagogía radical e inclusiva y educación para la muerte. Salamanca: Fahrenhouse. Recuperado em 6, marzo, 2017, de http://radicaleinclusiva.com/wpcontent/uploads/2018/01/portadaPedagradein-y-PM.pdf

Herrán, A. de la (2016a). La mala práctica educativa desde el enfoque radical de la formación. Boletin del Ilustre Colegio Oficial de Doctores y Licenciados en Filosofía y Letras y en Ciencias de Madrid (267), 10-12. Recuperado em 6, marzo, 2017, de http://radicaleinclusiva.com/wp-content/uploads/2018/01/malapracticaedu.pdf

Herrán, A. de la (2016b). Reflexiones pedagógicas desde el enfoque radical e inclusivo de la formación. Salamanca: Fahrenhouse. Recuperado em 6, marzo, 2017, de http://www.fahrenhouse.com/omp/index.php/fh/catalog/book/24

Herrán, A. de la (2017a). Sin meditación no hay educación. Boletín del Ilustre Colegio Oficial de Doctores y Licenciados en Filosofía y Letras y en Ciencias de Madrid. Apuntes de Pedagogía (269), 24-26. Recuperado em 4, junio, 2017, de https://www.cdlmadrid.org/wpcontent/uploads/2016/02/pedagogia0617.pdf

Herrán, A. de la (2017b). ¿Y si nuestra educación estuviese radicalmente equivocada? In A. Medina, A. de la Herrán, \& M. C. Domínguez (Coords.), Nuevas perspectivas en la formación de profesores. Madrid: Universidad Nacional de Educación a Distancia (UNED). Recuperado em 4, abril, 2017, de http://radicaleinclusiva.com/wpcontent/uploads/2018/12/educacionequivocada.pdf 


\section{pro.posıções}

http://dx.doi.org/10.1590/1980-6248-2017-0033

$e$-ISSN 1980-6248

Herrán, A. de la (2017c). Pedagogía radical e inclusiva. I. Problemas de la educación y la formación. In M. C. Domínguez Garrido, R. Ferreiro Gravié, A. de la Herrán Gascón, M. Medina, \& A. Medina Rivilla, Hacia una Didáctica del siglo XXI. Selección de lecturas. Zapopan (Jalisco, México): Universidad Santander (UNISAN). Recuperado em 4, abril, 2017, de http://radicaleinclusiva.com/wpcontent/uploads/2018/09/Pedagogia_radical_e_inclusiva_i_Introduccion_e_insuficie ncias.pdf

Herrán, A. de la (2017d). Pedagogía radical e inclusiva. II. Alternativas para la educación y la formación. In M. C. Domínguez Garrido, R. Ferreiro Gravié, A. de la Herrán Gascón, M. Medina, \& A. Medina Rivilla, Hacia una Didáctica del siglo XXI. Selección de lecturas. Zapopan (Jalisco, México): Universidad Santander (UNISAN). Recuperado em 4, abril, 2017, de http://radicaleinclusiva.com/wpcontent/uploads/2018/09/Pedagogia_radical_e_inclusiva_II_Alternativas.pdf

Herrán, A. de la (2018). Fundamentos para una Pedagogía del saber y del no saber. São Paulo (Brasil): Edições Hipótese. Recuperado em 4, junio, 2017, de https://drive.google.com/file/d/1dprFjWeqkKkOMS-AxCCZpe_UqU-64UnQ/view

Herrán, A. de la \& Álvarez, N. (2010). Para qué enseñar: significado y sentido de la formación universitaria. In J. Paredes, \& A. de la Herrán (Coords.), Cómo enseñar en el aula universitaria (pp. 59-74). Madrid: Pirámide. Recuperado em 4, abril, 2017, de http://radicaleinclusiva.com/wp-content/uploads/2018/01/formacionuniv.pdf

Herrán, A. de la, \& González, I. (2002). El ego docente, punto ciego de la enseñanza, el desarrollo profesional y la formación del profesorado. Madrid: Universitas.

Iranzo, P. (2012). Asesoramiento pedagógico al profesorado. Madrid: Síntesis.

Jay, J., \& Johnson, K. (2002). Capturing complexity: a typology of reflective practice for teacher education. Teaching and Teacher Education, 18(1), 73-85.

Johnston, W. (1980). La música callada. La ciencia de la meditación (3a ed.). Madrid: Paulinas (e.o.: 1974).

Josephson, M. (1959). Edison: A biography. New York: Mc Graw-Hill. 


\section{pro.posıções}

$e-I S S N$ 1980-6248

http://dx.doi.org/10.1590/1980-6248-2017-0033

Lao zi (2006). Tao te ching. Los libros del tao. Madrid: Trotta.

Latorre, A. (2008). La investigación-acción. Conocer y cambiar la práctica educativa. Barcelona: Graó.

Latorre, A. (2013). La investigación-acción. Barcelona: Graó.

Marín, J. (1961). Buda o la negación del mundo. Buenos Aires: Espasa-Calpe.

Mayor Zaragoza, F. (2000). Educar para la individualidad. Una formación permanente y de calidad para el siglo XXI. Acade (28), 18-22.

Mayor Zaragoza, F. (2009, Abril). Los grandes retos de la educación en el siglo XXI. In I. Núñez (Coord.), Educación, Ciencia, Cultura y Sociedad. Ciclo de conferencias. Madrid: Universidad Alfonso X el Sabio.

Medina, A. (2009). Innovación de la educación y de la docencia. Madrid: Ramón Areces-UNED.

Monarca, H. (2009). Los fines de la educación. Sobre la necesidad de recuperar y revisar el debate teleológico. Madrid: Narcea.

Morin, E. (2001). Los siete saberes necesarios para la educación del futuro. Barcelona: Paidós.

Morin, E. (2009). El octavo saber. Recuperado em 6, marzo, 2017, de http://www.youtube.com/watch?v=Uhwy4MZiFC0

Müeller-Commichau, W. (2016). Anerkennung als Medium. In G. Burkart, \& N. Meyer (Eds.), Die Welt anbalten (en prensa). Frankfurt: Goethe-Universität.

Muñoz, T. (2017). ¿Qué le sucede al cerebro en la meditación? Boletín del Ilustre Colegio Oficial de Doctores y Licenciados en Filosofía y Letras y en Ciencias de Madrid. Apuntes de Pedagogía (269), 21-23. Recuperado em 4, junio, 2017, de https://www.cdlmadrid.org/wpcontent/uploads/2016/02/pedagogia0617.pdf

Newton, I. (1686). Philosophice naturalis principia mathematica. Cambridge: University of Cambridge.

Nieto Díez, J. (1995). Hacia un modelo comprensivo de prácticas de enseñanza en la formación inicial del maestro (Tesis doctoral). Facultad de Educación, Centro de Formación del Profesorado, Universidad Complutense de Madrid, Madrid. 


\section{pro.posıções}

http://dx.doi.org/10.1590/1980-6248-2017-0033

$e$-ISSN 1980-6248

Nyanatiloka Mahathera (1990). La palabra del Buda. Barcelona: Índigo.

Osho (2007). Buda. Su vida y enseñanzas. Madrid: Océano-Gaia.

Palomero Pescador, J. E. (2011). La meditación en las aulas: asignatura pendiente. Recuperado em 6, marzo, 2017, de http://aufop.blogspot.com.es/2011/04/la-meditacion-en-las-aulasasignatura.html

Pannikar, R. (1969). La sonrisa de Buda. El silencio y la palabra. Revista de Occidente (176), 1-21

Pérez Pueyo, Á. (2013). Programar y evaluar competencias básicas en 15 pasos. Barcelona: Graó.

Perrenoud, P. (2012a). Cuando la escuela pretende preparar para la vida. ¿Desarrollar competencias o enseñar otros saberes? Barcelona: Graó.

Perrenoud, P. (2012b). Desarrollar la práctica reflexiva en el oficio de enseñar. Profesionalización y razón pedagógica. Barcelona: Graó.

Platón (1969). Apología de Sókrates. Madrid: Bergua.

Popkewitz, T. S. (2000). Sociología politica de las reformas educativas. Madrid: Morata.

Popkewitz, T. S. (2009). El cosmopolitismo y la era de la reforma escolar. Madrid: Morata.

Popkewitz, T.S. (2015). La práctica como teoría del cambio. Investigación sobre profesores y su formación. Profesorado. Revista de Curriculum y Formación del Profesorado, 19(3), 428453. Recuperado em 6, marzo, 2017, de http://www.redalyc.org/html/567/56743410015/

Ramírez, M. S., \& de la Herrán, A. (2012). La madurez personal en el desarrollo profesional del docente. REICE. Revista Iberoamericana sobre Calidad, Eficacia y Cambio en Educación, 10(3), 25-44. Recuperado em 6, marzo, 2016, de https://revistas.uam.es/index.php/reice/article/view/3039

Rawding, F. W. (1991). Buda. Madrid: Akal (e.o.: 1975).

Real Academia de la Lengua Española (2015). Diccionario de la lengua española (23a ed.). Recuperado em 6, marzo, 2017, de: http://www.rae.es/ 


\section{pro.posıções}

e-ISSN 1980-6248

http://dx.doi.org/10.1590/1980-6248-2017-0033

Rodríguez Marcos, A., Esteban, R. M., Aranda, R., Blanchard, M., Domínguez, C., González, P., Romero, P. ..., \& Messina, C. (2011). Coaching reflexivo entre iguales en el prácticum de la formación de maestros. Revista de Educación (355), 355-379. Recuperado em 6, abril, 2017, de http://www.revistaeducacion.educacion.es/re355/re355_15.pdf

Rodríguez Marcos, A., \& Pessoa, T. (2011). A vida nas escolas. La práctica cotidiana en los colegios. Casos para la formación de docentes. Coimbra: Universidade de Coimbra.

Rozada, J. M. (1997). Los profesores en la encrucijada por donde pasan sólo (aunque también) las disciplinas. Investigación en la Escuela, (32), 87-96.

Ruffinelli, A. (2017). Formación de docentes reflexivos: un enfoque en construcción y disputa. Educação e Pesquisa, 43(1), 97-111 Doi: http://dx.doi.org/10.1590/S15179702201701158626

Santos Guerra, M. Á. (1999). Crítica de la eficacia y eficacia de la crítica: lo verdadero, lo verosímil y lo verificable en el análisis de las instituciones educativas. In F. Angulo Rasco, Á. Pérez Gómez, J. Gimeno Sacristán, M. Á. Santos Guerra, X. Torres Santomé, \& M. López Melero, Escuela pública y sociedad neoliberal. Madrid: Niño y Dávila.

Savater, F. (1997). El valor de educar. México: Instituto de Estudios Educativos y Sindicales de América.

Schön, D. (1998). El profesional reflexivo: cómo piensan los profesionales cuando actúan. Barcelona: Paidós.

Schön, D. A. (1992). Formar professores como profissionais reflexivos. In A. Nóvoa (Coord.), Os professores e sua formação (pp. 77-91). Lisboa: Dom Quixote.

Schön, D. A. (2002). La formación de profesionales reflexivos. Barcelona: Paidós.

Scott, C. (1998). Buda. Madrid: Edimat.

Sevillano, M. L. (2007). Investigar para innovar en enseñanza. Madrid: Pearson.

Sevillano, M. L. (2011). Didáctica en el núcleo de la Pedagogía. Tendencias Pedagógicas (18), 15 37. 


\section{pro.posıções}

http://dx.doi.org/10.1590/1980-6248-2017-0033

$e$-ISSN 1980-6248

Torres Santomé, J. (2007). Educación en tiempos de neoliberalismo. Madrid: Morata.

Valverde, A., Ruiz de Miguel, C., García, E., \& Romero, S. (2004). Innovación en la orientación universitaria: la mentoría como respuesta. Contextos educativos. Revista de Educación (6-7), 87-112.

Vélaz de Medrano Ureta, C. (2009). Competencias del profesor-mentor para el acompañamiento al profesorado principiante. Profesorado. Revista de Currículum y Formación del Profesorado, 13(1), 209-229.

Yutang, L. (1961). El nombre secreto. Buenos Aires: Editorial Sudamericana.

Zambrano, M. (2004). Hacia un saber sobre el alma. Madrid: Alianza.

Zeichner, K. (1993). El maestro como profesional reflexivo. Cuadernos de Pedagogía (220), 44-49.

Zhuang zi (1996). Zhuang qi. Barcelona: Kairós

Submitted to evaluation on February 27, 2017; revised on November 12, 2017; accepted for publication on December 20, 2017. 